\begin{tabular}{|c|c|c|c|}
\hline & $\begin{array}{c}\text { International Journal of Current Research in } \\
\text { Biosciences and Plant Biology }\end{array}$ \\
\hline EXCELLENT \\
PUBLISHERS
\end{tabular}

Original Research Article

doi: https://doi.org/10.20546/ijcrbp.2021.809.004

\title{
Three species of acrocarpous mosses, distributional records to the Bryoflora of Peninsular India
}

\author{
Ananthaneni Sreenath $\left(\mathbb{D}^{1}\right.$ and Boyina Ravi Prasad Rao $\mathbb{D}^{2} *$

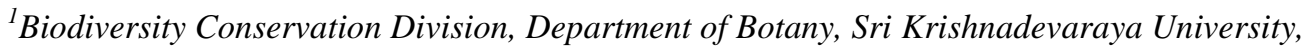 \\ Ananthapuramu - 515 003, Andhra Pradesh, India \\ ${ }^{2}$ Biodiversity Conservation Division, Department of Botany, Sri Krishnadevaraya University, \\ Ananthapuramu - 515 003, Andhra Pradesh, India \\ *Corresponding author; e-mail: biodiversityravi@gmail.com \\ Phone \& Fax: 08554-255019, Mobile: 09440705602
}

\begin{abstract}
Article Info Abstract
Keywords: $\quad$ Three species of acrocarpous mosses, viz., Entosthodon wallichii Mitt. (Funariaceae), Splachnobryum Bryoflora of aquaticum Mull.Hal. (Splachnobryaceae), and Tortula rubripila Dixon (Pottiaceae), collected from Peninsular India different localities of Andhra Pradesh, are new distributional records for Peninsular India.

Entosthodon

Splachnobryum

Tortula
\end{abstract}

- Received: 21 July 2021 • Revised: 28 August 2021 • Accepted: 30 August 2021 • Published Online: 6 September 2021

\section{Introduction}

The Peninsular India bounded on the west by the Arabian Sea, on the east by the Bay of Bengal and on the north by the Vindhya and Satpura ranges. Covering an area of about 16 lakh $\mathrm{km}^{2}$, the peninsular upland forms the largest physiographic division of India, bounded by the Aravallis in the North West, Hazaribagh and Rajmahal Hills in the northeast, the Western Ghats (Sahayadri Mountains) in the west and the Eastern Ghats in the east. The highest peak of Peninsular India is Anamudi, $2695 \mathrm{~m}$ above sea level. The study area Andhra Pradesh covers major portion of Eastern Ghats, and covers an area about 162, $970 \mathrm{sq}$. $\mathrm{km}$. The state comprises 13 districts, four of which constitute Rayalaseema region and remaining nine districts, coastal Andhra Pradesh. The state comprises, 17.86 per cent of forest cover (FSI 2019) and harbor over 180 waterfalls.

Extensive field explorations conducted for bryophytes in the state of Andhra Pradesh during June 2016 to February 2020 yielded some curious acrocarpous moss specimens which after critical investigation identified belonging to Entosthodon wallichii Mitt. (Funariaceae), Splachnobryum aquaticum Mull.Hal. (Splachnobryaceae), and Tortula rubripila Dixon (Pottiaceae). Perusal of literature (Daniels, 2010; Dandotiya et al., 2011; 
Sandhya Rani et al., 2014; Alam 2015; Alam et al., 2015; Mishra et al., 2016; Magdum et al., 2018, Singh et al., 2018; Sreenath \& B.R.P. Rao 2019 A \& B; Bryophytes of Kerala 2020) revealed that these species were not recorded so far from Andhra Pradesh as well from any locality in Southern Peninsular India and hence form new records. Present report also added two more generic additions (Tortula, Entosthodon) to Andhra Pradesh.

\section{Materials and methods}

The corticolous plant material was collected by using sharp edged knife and terrestrial specimens were scraped by using manually bent and sharped flat spoon. The collected specimens were placed in zip lock polythene cover with labeled field number. Field observations were recorded in the field notes and live photographs were taken using Nikon Camera. Collected material brought to the laboratory, made it air dried and preserved them in brown paper packets $(12 \times 18 \mathrm{~cm})$ with detailed label $(10 \times 17 \mathrm{~cm})$. Critical examination of the specimens was done by using micro forceps (Varin) VR-15 curved, VR-11 straight with fine sharp edges and slides were observed under light microscope (Olympus CH20i), light stereo microscope (Olympus SZ61); micro measurements were taken by using ocular micro meter (ERMA) $19 \mathrm{~mm}$. Photographs were taken by using Moto g3 turbo and Samsung on6 equipped with $13 \mathrm{MP}$ camera with $4 \mathrm{x}$ wide digital zoom. Identification of the specimens was done by using standard floras. Descriptions, habitat \& ecology, voucher specimens' information, field photographs were provided for all the species. Voucher specimens were deposited in Sri Krishnadevaraya University Herbarium (SKU) Ananthapuramu. Abbreviated names for the collectors are: AS (Ananthaneni Sreenath) and BR (Boyina Ravi Prasad Rao).

\section{Results}

Entosthodon wallichii Mitt., J. Proc. Linn. Soc., Bot., Suppl. 1: 55 1859; Gangulee, Mosses Eas. India, 2(4): 851 - 852. 1974 (FUNARIACEAE) (Fig. 1).

Plants small sized, laxly gregarious to tufted, yellowish green to green, up to $7 \mathrm{~mm}$ high, generally unbranched. Few small lax leaves on lower stem, larger leaves forming a rosette at top, erect to spreading when moist, crumpled and clinging to stem when dry. Leaves obovate-lanceolate to oblong lanceolate, $1.2-1.6 \times$
$0.35-0.5 \mathrm{~mm}$, apex prolonged in to an arista, margin usually dentate in the upper part. Costa ending a little below the apex. leaf cells thin-walled, large rectangular, basal cells $98-105 \times 9-11 \mu \mathrm{m}$, narrower and hexagonal to rhomboidal at apex, cells $72-78 \times 9-11$ $\mu \mathrm{m}$; arista up to $0.2 \mathrm{~mm}$ long; leaf marginal cells narrower (with pointed ends causing very mild dentation at apex) forming a somewhat distinct border. Seta apical, erect up to $1.5 \mathrm{~cm}$ long, somewhat flexuose when dry, reddish brown. Capsule erect or slightly inclined, symmetrical, elongated pyriform with a tapering apophysis as long as capsule, $2.7-3.1 \mathrm{~mm}$ long with apophysis $\times 0.8-1 \mathrm{~mm}$ in diameter wide at urn, urn mouth narrower than capsule; exothecial cells vertical rectangular with 5 or 6 rows of horizontally rectangular, tinted cells at rim. Peristome missing. Operculum conical convex with a very rudimentary apiculus. Spores reddish brown, rounded, rough warty, up to $32 \mu \mathrm{m}$ in diameter.

Habitat and ecology: Saxicolous near cement wall, slightly covered with moist soil, in moist deciduous forests, associated with other acrocarpous mosses.

Specimens examined: India, Andhra Pradesh, Chittoor district, Horsley hills, 16 September 2016, 51661, SKU, BR \& AS.

Distribution: World: Nepal, Philippines and India: Meghalaya, Uttar Pradesh, Uttarakhand and West Bengal.

Splachnobryum aquaticum Mull. Hal. Linnea 40: 291. 1876. Splachnobryum giganteum Broth. Symb. Sin. 4: 49. 1929; Splachnobryum procerrimum Dixon \& P. de la Varde, Ann. Cryptog. Exot. 1: 38. 2 f. 2. 1928; Theo. Arts, A revision of the Splachnobryaceae (Musci). Lindbergia 26: 82 - 83 . 2001 (SPLACHNOBRYACEAE) (Fig. 2).

Plants small to medium, yellowish green to pale green, stem usually unbranched, rarely branched, up to $5 \mathrm{~cm}$ high, soft flexuose when moist, curled to crumpled when dry; leaves alternate to spiral, sparse below and more crowded towards apex, erect to spreading and more or less recurved $1.2-2.5 \times 0.5-1.2 \mathrm{~mm}$, upper leaves often particularly longer than the lower leaves, elliptic, with obtuse to rounded apex; costa slender ending far below the apex; leaf margin plane or narrowly recurved below on one or both sides, more or less crenulate at apex; leaf base semi-amplexicaul, 
narrowly decurrent; leaf cells smooth, thin-walled, upper and middle leaf cells oblong hexagonal $35-80 \times$ $15-32 \mu \mathrm{m}$, some extreme tip and marginal cells slightly shorter $30-50 \times 15-25 \mu \mathrm{m}$; basal cells rectangular; axillary hairs usually arising in pairs, about $100 \mu \mathrm{m}$ long, consisting of two colorless basal cells 12 $-17 \times 9-12 \mu \mathrm{m}$ and terminal clavate cells $62-75 \times$
$14-17 \mu \mathrm{m}$, paraphysis absent, sporophytes are not seen.

Habitat and ecology: Rupicolous on wet rock under continuous water dropping areas like waterfalls, available as a monodominant plant and sometimes associated with other algae.

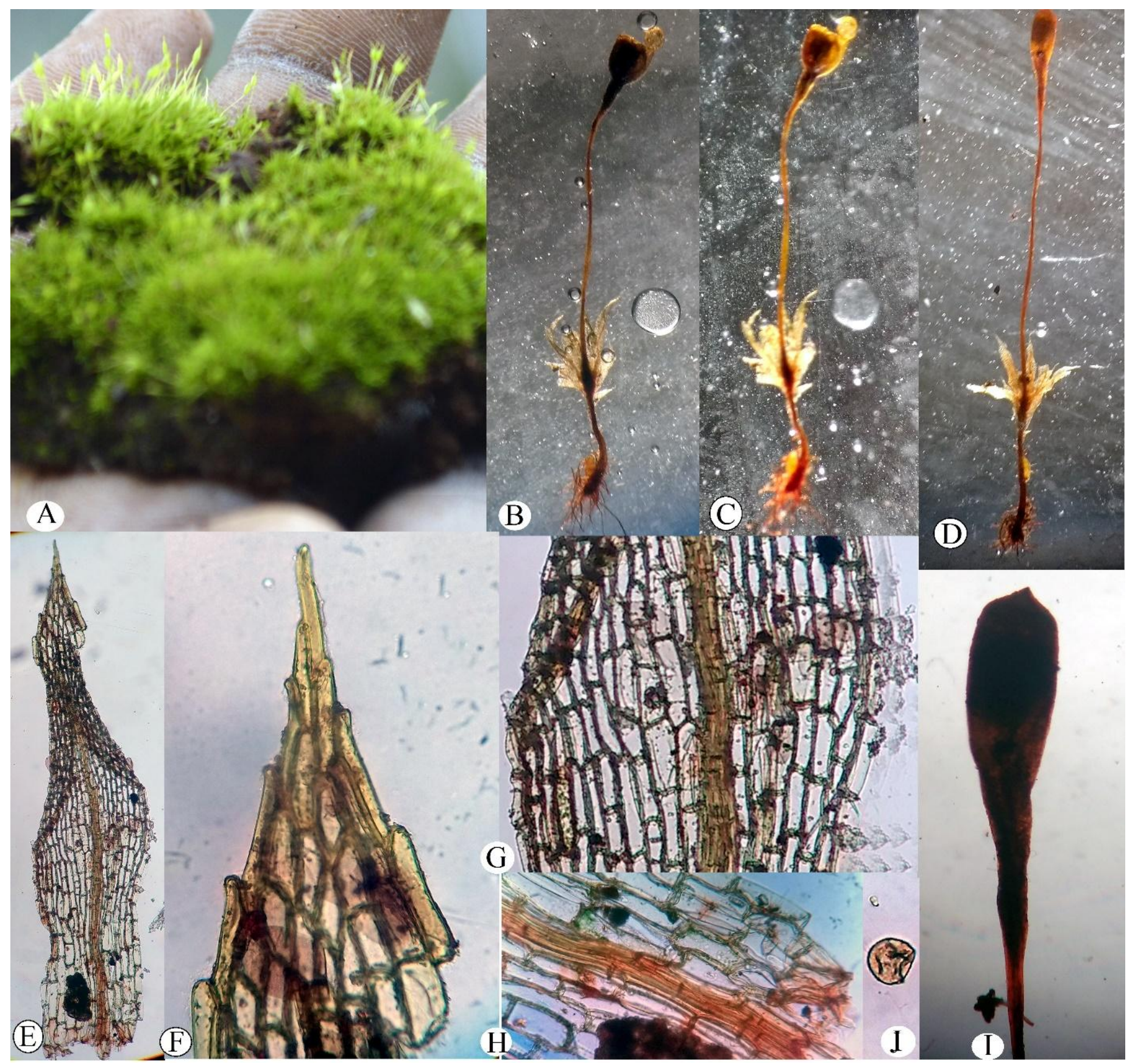

Fig. 1: A - J. Entosthodon wallichii, A. Habit, B, C \& D: Magnified view of single plants, E. Magnified view of Leaf, F. Leaf apical cells, G. Leaf middle cells, H. Leaf Basal cells, I. Magnified view of Capsule with apophysis and J. Spore. 


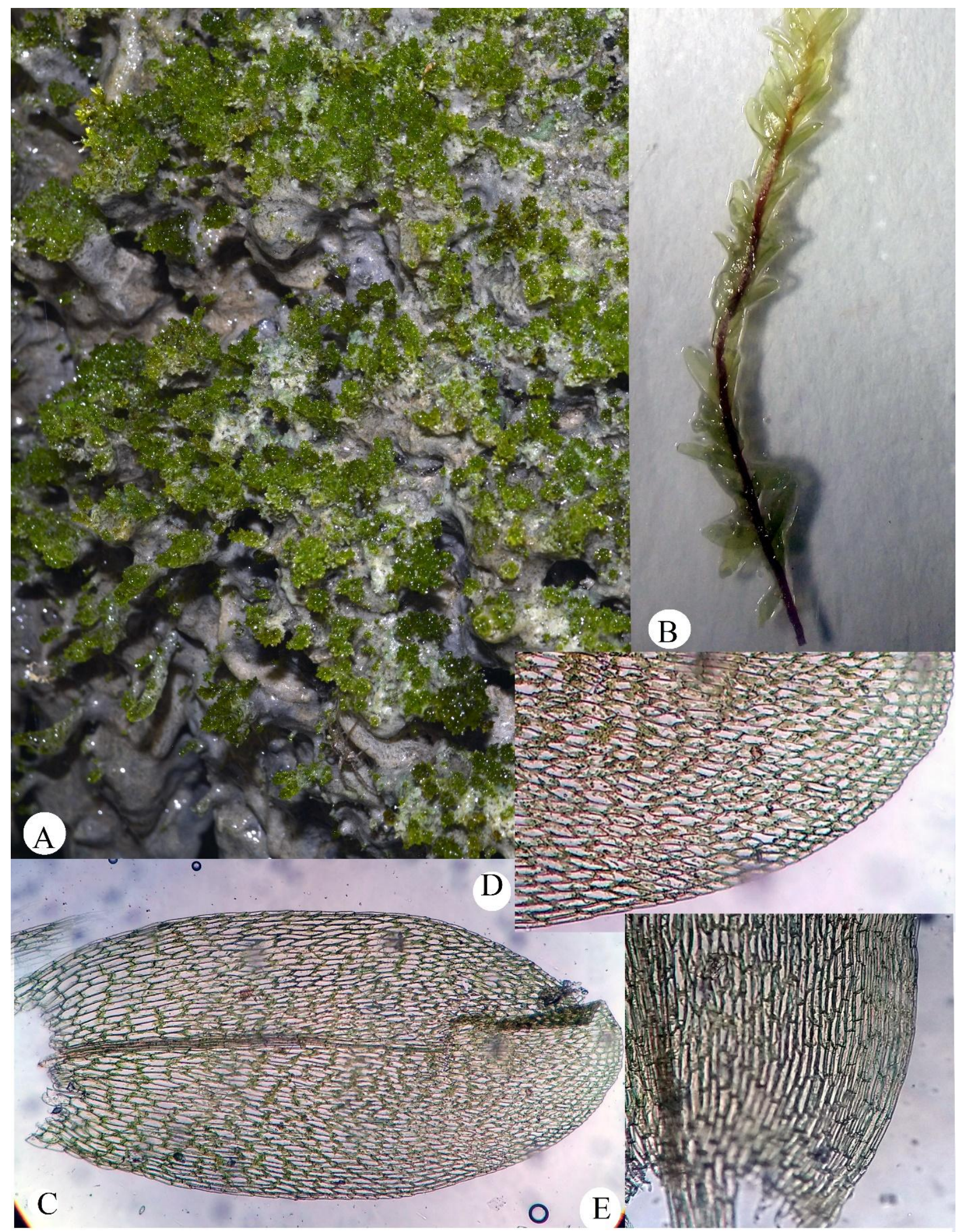

Fig. 2: A - E. Splachnobryum aquaticum, A. Habit, B. Magnified view of single plant, C. Magnified view of Leaf, D. Leaf apical cells and E. Leaf middle and basal cells. 
Tortula rubripila Dixon., Ann. Bryol. 3: 58 1930; Chopra R.S. Tax. of Indian mosses: 160. 1975 (POTTIACEAE) (Fig. 3).

Plants small, in yellowish green to brownish green, reddish brown below. Stem erect, up to $1.5 \mathrm{~cm}$ high, usually unbranched, rarely branched, radiculose below. Leaves erect to spreading to slightly reflexed when moist; curved to crisped when dry, oblong-ligulate to elliptic,
$0.9-1.6 \times 0.4-0.6 \mathrm{~mm}$, rounded to obtuse at apex, weakly sheathing at base; margins recurved or revolute near and above the mid leaf, entire or rarely crenulate by projecting papillae, costa thick, strong, reddish brown, excurrent as slightly long arista, arista reddish brown. Leaf apical and middle cells quadrate to roundedhexagonal, $9-12 \times 7-8 \mu \mathrm{m}$, basal cells slightly larger, slightly elongated and quadrate-rectangular, $12-15 \times 9-$ $11 \mu \mathrm{m}$. Sporophytes are not seen.

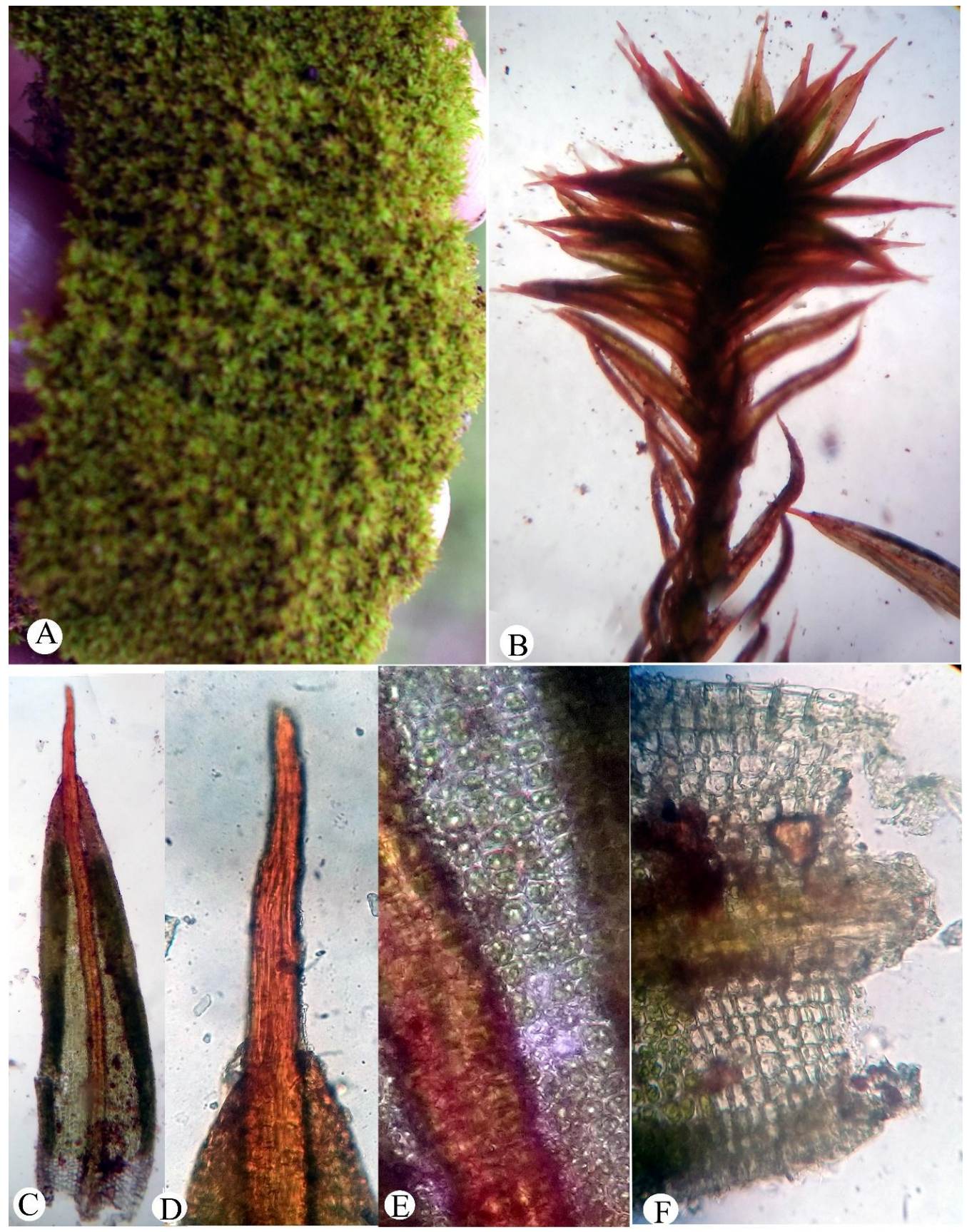

Fig. 3: A - F. Tortula rubripila, A. Habit, B. Magnified view of single plant, C. Magnified view of Leaf, D. Magnified view of costa tip and leaf apical cells, E. Leaf middle cells and F. Leaf basal cells. 
Habitat and ecology: Terricolous on forest floor of moist deciduous forests, as mono-dominant plant or sometimes associated with other mosses or Ricciaceae members.

Specimens examined: India, Andhra Pradesh, Kurnool district, Nallamalais, Rajiv Gandhi wild life sanctuary, 5 $\mathrm{km}$ beside from Srisailam, near Biolab Sunnipenta, 28 May 2017, 53389, SKU, BR \& AS; Kadapa district, Lankamalleswaram WLS, Lankamal hills, 01 December 2019, $57043 \&$ 57052B, SKU, AS.

Distribution: World: Australia, Brazil, Canada, Egypt, Iraq, Japan, Namibia, New Zealand, Philippines, South Africa, United States and India: Jammu \& Kashmir.

Specimens examined: India, Andhra Pradesh, Aananthapuramu district, Alurkona, Waterfalls, near Ranganayakulu swami temple, 27 November 2016, 52204, SKU, AS; Kurnool district, Nallamalais, Siddaramappa kolanu waterfalls, 31 May 2016, 53393, SKU, BR \& AS.

Distribution: World: Bhutan, China, Nepal, Pakistan, Philippines, Somalia, Thailand, UAE, Yemen and India (Gujarat and Uttarakhand).

\section{Conflict of interest statement}

Authors declare that they have no conflict of interest.

\section{Acknowledgement}

Authors thank Andhra Pradesh Forest Department for according permission for field work. We thank Dr. M. Anil Kumar, Mr. P. Anjaneyulu and Mr. S.M. Nagesh for their help in field work. Thanks are due to home university administration for providing research facilities.

\section{References}

Alam, A., 2015. Moss flora of India. An updated summary of taxa. Grain Verlag publications, Viii + 185.

Alam, A., Rawat, K. K., Verma, P. K., Sharma, V., Gupta, D. S. 2015, Moss flora of Central India. Plant Sci. Today, 2(4): 159-171.

Bryophytes of Kerala, 2021. Envis center, Kerala, (Cited 2021 March 15), Available from: http://www.kerenvis.nic.in/Database/Bryophytes2137.aspk

Dandotiya, D., Govindapyari, H., Suman, S., Uniyal, P. L., 2011. Check list of the Bryophytes of India, Arch. Bryol., 88: 1-126.

Daniels, A. E. D., 2010. Checklist of the bryophytes of the Tamil Nadu, India. Arch. Bryol., 65: 1-118.

Magdum, S. M., Patil. S. M., Lavate R. A., Dongere, M. M., 2018, Checklist of Mosses from Western Ghats of Maharashtra, India. Biosci. Discov., 8(1): 73-81.

Mishra, M., Dash, P. K., Alam, A., Sahoo, S., Das R., 2016, Current Status of diversity and distribution of Bryophytes of Odisha. Plant Sci. Today, 3(2): 186194.

Sandhya Rani, S., Sowghandhika, M., Nagesh, K. S., Suseela, B., Pullaiah, T., 2014 Bryophytes of Andhra Pradesh. Bishen Singh Mahendra Pal Singh, Dehra Dun.

Singh. D. K., Singh, S. K., Singh, D., 2021. Bryophytes of Karnataka: A Checklist 2018. (Cited 2021 May 21): Available from. https://karunadu.karnataka. gov.in/kbb/english/Pages/ Bryophytes-of-karnataka. aspx

Sreenath, A., Ravi Prasad Rao, B., 2020, Pseudephemerum (Limb.) I. Hagen (Dicranaceae, Dicranales, Bryopsida) A new generic record to Peninsular India. Ann. Plant Sci., 9(3): 3761-3766.

\section{How to cite this article:}

Sreenath, A., and Ravi Prasad Rao, B., 2021. Three species of acrocarpous mosses, distributional records to the Bryoflora of Peninsular India. Int. J. Curr. Res. Biosci. Plant Biol., 8(9): 28-33.

doi: https://doi.org/10.20546/ijcrbp.2021.809.004 